\title{
Endoplasmic Reticulum (Rough)
}

National Human Genome Research Institute (NHGRI)

\section{Source}

National Human Genome Research Institute (NHGRI). Endoplasmic Reticulum (Rough).

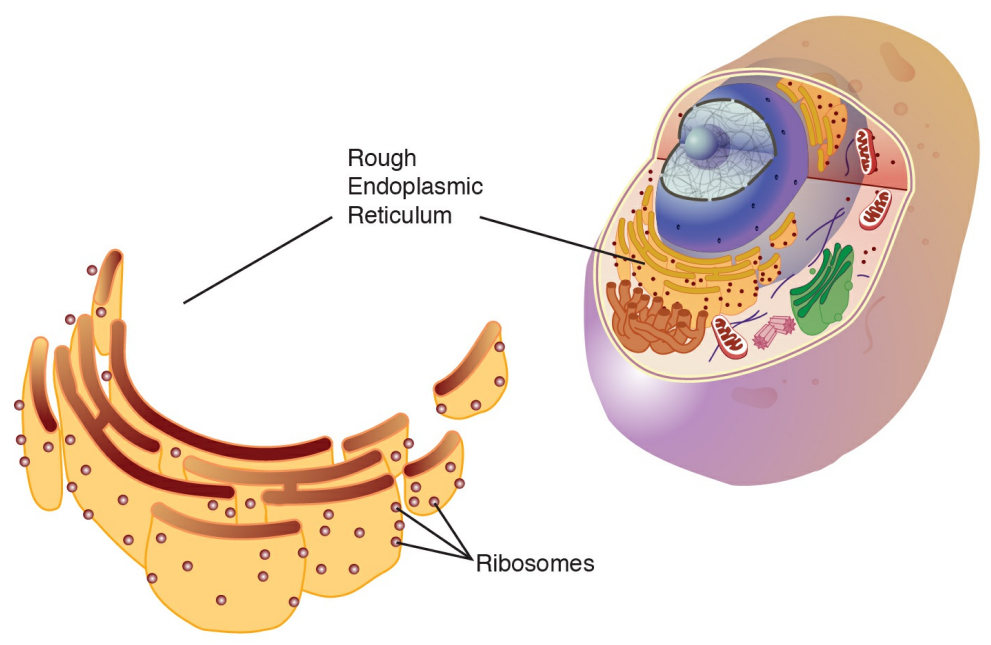

Endoplasmic reticulum is a network of membranes inside a cell through which proteins and other molecules move. Proteins are assembled at org anelles called ribosomes. When proteins are destined to be part of the cell membrane or exported from the cell, the ribosomes assembling them attach to the endoplasmic reticulum, giving it a rough appearance. 